\title{
PEMBUATAN PULP MEKANIS TANDAN KOSONG SAWIT UNTUK KERTAS LAINER DAN MEDIUM
}

\author{
Erwinsyah $^{\text {a }}$, Susi Sugesty ${ }^{\mathrm{b}}$, Taufan Hidayat ${ }^{\mathrm{b}}$ \\ a Pusat Penelitian Kelapa Sawit - Medan \\ ${ }^{\mathrm{b}}$ Balai Besar Pulp dan Kertas \\ Jl. Raya Dayeuhkolot 132 Bandung 40258 Tlp. (022) 5202980 Fax. (022) 5202871 \\ Diterima : 15 Maret 2012, Revisi akhir : 28 Mei 2012

\section{KRAFT LINER AND CORRUGATING MEDIUM FROM MECHANICAL PULP EMPTY FRUIT BUNCHES OF PALM OIL}

\begin{abstract}
The process of CTMP and APMP were used to make mechanical pulp from Empty Fruit Bunches of Palm Oil (EFBPO). These pulps then used for kraft liner making with the EFBPO - OCC composition of 50-50 and 75-25, and corrugating medium of 100\% EFBPO. The best kraft liner is obtained from CTMP - OCC with 75-25 composition, and corrugating medium from CTMP 100\%. Both results meet the requirements of B Class of National Standard of Indonesia.
\end{abstract}

Keywords: EFBPO, CTMP, APMP, kraft liner, corrugating medium

\begin{abstract}
ABSTRAK
Pulp tandan kosong sawit (TKS) diproduksi dengan proses pulp semi-kimia (CTMP) dan Alkaline Peroxide Mechanical Pulping (APMP). Pulp tersebut selanjutnya dibuat kertas lainer dengan persen komposisi pulp TKS - OCC masing-masing 50-50 dan 75-25, serta kertas medium dengan komposisi $100 \%$ TKS. Hasil percobaan menunjukkan bahwa kertas lainer terbaik diperoleh dari campuran 75\% pulp CTMP dan 25\% OCC, bersesuaian dengan persyaratan SNI Kertas Liner B, sedangkan kertas medium yang terbuat dari 100\% pulp CTMP memenuhi syarat SNI Kertas Medium B.
\end{abstract}

Kata kunci: TKS, CTMP, APMP, kertas lainer, kertas medium

\section{PENDAHULUAN}

Pada saat ini Indonesia menduduki peringkat ke-9 sebagai produsen pulp dunia dengan pangsa pasar sebesar $2,4 \%$ terhadap dunia dan sementara itu sebagai produsen kertas Indonesia menduduki peringkat ke-9 dengan pangsa pasar sebesar 2,2\% terhadap dunia (IPPA, 2011). CEPI (Confederation of European Paper Industries) memproyeksikan konsumsi dunia akan pulp berjumlah 233 juta ton pada tahun 2015 dengan pertumbuhan $1,8 \%$ per tahun dan kertas sebesar 458 juta ton per tahun dengan pertumbuhan sekitar $2,9 \%$ per tahun. Hal ini menunjukkan bahwa kebutuhan pulp dan kertas dunia masih cukup besar dan Indonesia berpeluang untuk ikut bermain dalam pasar pulp dan kertas dunia. Di samping peluang di dunia tersebut, maka peluang di dalam negeri juga cukup besar. Konsumsi per kapita kertas per tahun di Indonesia terus meningkat, untuk tahun 2004 dan 2005 mencapai $25,3 \mathrm{~kg}$ dan pada 2006 meningkat menjadi $25,4 \mathrm{~kg}$. Selanjutnya, diperkirakan untuk tahun mendatang kenaikan konsumsi per kapita nasional dapat mencapai 7,0 - 8,0\% per tahun (Driektori APKI 2011). Menurut catatan APKI total kertas yang diproduksi selama 5 tahun terakhir rata-rata sebesar 7,27\% dan total konsumsi kertas rata-rata $5,87 \%$.

Bahan baku pulp, baik dari kayu (wood) maupun non-kayu (non-wood) adalah bahan baku dasar dalam proses pembuatan pulp (termasuk bleach kraft pulp maupun dissolving kraft pulp). Teknologi untuk pembuatan pulp kayu dapat diimplementasikan untuk pembuatan pulp non-kayu (Rolf, 2009), termasuk di dalamnya penggunaan berbagai jenis enzim seperti selulase, hemiselulase, lipase, esterase, 
pektinase, dan amylase (Tandon, 2009). Menurut para ahli, negara-negara mempunyai kemampuan mengembangkan industri pulp dan kertas sangat terbatas, kecuali Brazil dan Indonesia yang areal hutannya masih sangat luas, sedangkan negaranegara NORSCAN (Amerika Serikat, Kanada, Swedia, Finlandia) sebagai negara eksportir pulp dan kertas terbesar di dunia sudah tidak mengembangkan industri pulp dan kertasnya seperti HTI di Indonesia, karena sebagian besar hutannya sudah digunakan untuk pulp wood plantation.

Pengembangan hutan tanaman industri (HTI) sampai saat ini kurang berhasil mengimbangi laju kebutuhan pasokan bahan baku yang semakin besar jumlahnya. Ada kecenderungan tidak terpenuhinya pasokan bahan baku kayu untuk pulp dan kertas, sehingga kemungkinan investasi pulp bernilai triliunan rupiah terancam batal. Bertolak dari kondisi yang memprihatinkan tersebut, sebenarnya masih ada solusi yang sangat menentukan untuk tetap berlangsungnya industri pulp dan kertas di Indonesia. Salah satu solusi yang sangat relevan adalah memproduksi pulp dengan menggunakan bahan baku nonkayu dengan memanfaatkan serat dari biomassa. Hal ini juga dapat menjaga kelestarian hutan di Indonesia.

Salah satu jenis sumber serat pulp adalah biomassa yang terdapat di perkebunan kelapa sawit. Bahan baku tersebut banyak dijumpai dan potensinya sangat besar (Tjahjono, 2005). Salah satu diantaranya adalah tandan kosong sawit (TKS). Setiap pabrik minyak sawit mentah akan menghasilkan TKS kering rata-rata 7-15 ton/jam, jadi untuk setiap tahunnya dapat menghasilkan $55440-118800$ ton (Erwinsyah, 2000). Dengan semakin meningkatnya areal penanaman kelapa sawit setiap tahunnya ketersediaan TKS akan semakin meningkat juga. Hasil penelitian yang dikembangkan oleh Balai Besar Pulp dan Kertas menunjukkan bahwa TKS dapat dibuat pulp dengan kekuatan yang cukup tinggi dan pulp tersebut dapat dipergunakan untuk bahan baku kertas tulis cetak, substitusi kertas kantong semen dan kertas HVO. TKS memiliki panjang serat rata-rata $0,74 \mathrm{~mm}$ dan diameter luar $10,14 \mu \mathrm{m}$ serta tebal dinding $3,52 \mu \mathrm{m}$.

Kertas lainer merupakan jenis kertas industri yang digolongkan sebagai karton. Kertas ini digunakan sebagai pelapis dan penyekat antar kertas medium bergelombang pada karton gelombang (KG). Salah satu sifat penting kertas lainer adalah ketahanan tekan (Considine, 2010). Kertas liner biasanya dibuat dengan mesin Fourdrinier dari bahan baku berupa pulp asli (virgin pulp) kayu dengan proses kraft dicampur dengan kotak karton gelombang bekas atau OCC. Karena penggunaan kertas lainer terus meningkat, maka impor kertas bekas juga meningkat, sementara itu laju daur ulang kertas bekas di Indonesia juga masih cukup rendah. Jika pembuatan karton menggunakan serat asli (virgin pulp) maka tidak akan menimbulkan masalah limbah padat berupa logam berat. Virgin pulp dapat berasal dari kayu maupun non-kayu, di negara maju biasanya kertas lainer bermutu tinggi dibuat dari kayu. Oleh karena itu, harus mulai dipikirkan penggunaan bahan baku kertas lainer dan medium yang seluruhnya berasal dari Indonesia. Salah satu alternatif yang mungkin adalah pemanfaatan TKS sebagai limbah industri hasil perkebunan yang tersedia cukup melimpah di Indonesia. TKS dapat digunakan sebagai bahan baku virgin pulp yang dapat menggantikan kertas bekas pada pembuatan lainer.

\section{BAHAN DAN METODE}

Bahan baku yang digunakan dalam penelitian ini berupa tandan kosong sawit dengan kadar air rata-rata $30 \%$. Untuk keperluan analisa bahan kimia, TKS dibuat menjadi serbuk menggunakan alat penyerbuk Wiley lalu disaring sampai diperoleh ukuran $40-60$ mesh. Analisa komponen kimia bahan baku menurut SNI meliputi kadar holoselulosa, alfa selulosa, lignin, pentosan, abu, sari, kelarutan dalam air dingin, air panas dan dalam 1\% $\mathrm{NaOH}$. Penentuan morfologi serat TKS meliputi panjang serat, tebal dinding serat dan nilai turunannya yaitu bilangan Runkle, kelangsingan dan kelemasan menurut prosedur Franklin Forest Product Research Laboratory US Department of Agriculture dan Standar Nasional Indonesia (SNI).

Pembuatan pulp dilakukan melalui dua cara yaitu proses semikimia (CTMP) dan Alkaline Peroxide Mechanical Pulping (APMP). Proses semikimia meliputi pemanasan serat TKS dengan steam pada suhu $100^{\circ} \mathrm{C}$ selama 1 jam kemudian ditambahkan bahan kimia $\mathrm{NaOH}$ dalam autoclave dengan variasi 4, 6, 8 dan $10 \%$. Pembuatan pulp dilakukan dalam rotary digester pada suhu $120-135{ }^{\circ} \mathrm{C}$ dimana waktu pada suhu maksimum $1-2$ jam. Serat TKS selanjutnya diuraikan dalam refiner 2 tingkat yaitu refiner 
kasar dan refiner halus. Setelah itu dilakukan penyaringan menggunakan saringan bergetar untuk memisahkan serat-serat halus dan seratserat kasar. Selanjutnya dari serat-serat halus (pulp) ditentukan rendemennya.

Pembuatan pulp APMP meliputi impregnasi serpih dengan steam pada suhu $100^{\circ} \mathrm{C}$ selama 1 jam dan penguraian serat kasar. Selanjutnya impregnasi kimia yang dibagi menjadi dua tahap yaitu impregnasi kimia-1 (penambahan DTPA $1 \%, \mathrm{Na}_{2} \mathrm{SiO}_{3} 1,3 \%, \mathrm{NaOH} 1,8 \%, \mathrm{H}_{2} \mathrm{O}_{2} 1,4 \%$ ) pada suhu $80^{\circ} \mathrm{C}$ selama 2 jam dan impregnasi kimia-2. Impregnasi kimia-2 dibagi menjadi tiga target. Target low brightness dengan penambahan $\mathrm{Na}_{2} \mathrm{SiO}_{3} 2 \%, \mathrm{NaOH} 1,8 \%$ dan $\mathrm{H}_{2} \mathrm{O}_{2} 2 \%$ pada suhu kamar selama 2 jam. Target mid brightness dengan penambahan $\mathrm{Na}_{2} \mathrm{SiO}_{3} 3 \%$, NaOH 3,8\% dan $\mathrm{H}_{2} \mathrm{O}_{2} 4 \%$ pada suhu kamar selama 2 jam. Target high brightness dengan penambahan $\mathrm{Na}_{2} \mathrm{SiO}_{3} 4 \%, \mathrm{NaOH} 4,5 \%$ dan $\mathrm{H}_{2} \mathrm{O}_{2} 6 \%$ pada suhu kamar selama 2 jam. Selanjutnya refining tahap pertama untuk mendapatkan pulp mekanis dengan konsistensi $10-15 \%$. Refining tahap kedua untuk mengetahui tingkat pekembangan kekuatan dan kemampuan serat untuk membentuk lembaran di atas mesin kertas. Tahap terakhir pencucian pulp dari sisa bahan kimia dan penyaringan agar diperoleh kualitas produk akhir pulp mekanis yang seragam.

Pengujian sifat fisik lembaran pulp meliputi uji ketahanan sobek kertas (SNI 14-0436-1998), uji ketahanan retak pulp dan kertas (SNI 14-04931998), uji sifat tarikan (SNI ISO 1924-2:1994) dan uji tebal lembaran (SNI 14-0435-1998). Selain itu dilakukan juga pengujian derajat putih dengan SNI ISO 2470: 1999. Untuk pembuatan kertas lainer digunakan pulp CTMP (2 kondisi pulping) dan pulp APMP (2 kondisi pulping) serta OCC yang diperlukan untuk menambah kekuatan lembaran kertas. Kertas lainer dibuat dari campuran $50 \%$ pulp TKS $+50 \%$ OCC dan $75 \%$ pulp TKS $+25 \%$ OCC, sedangkan lapisan tengah terbuat dari $100 \%$ pulp.

\section{HASIL DAN PEMBAHASAN}

Serat TKS yang diteliti ini mempunyai morfologi serat yang cukup baik yaitu panjang serat rata-rata $1,11 \mathrm{~mm}$., termasuk ke dalam kelompok serat pendek $(<1,44 \mathrm{~mm})$. Diameter luar dan dalam berturut-turut adalah 10,34 dan 21,67 $\mu \mathrm{m}$. Kelangsingan (L/D x 1000), kekakuan $(\mathrm{w} / \mathrm{D})$ dan kelenturan (1/D) berturut-turut adalah
51,01; 0,26 dan 0,48. Sedangkan tebal dinding adalah 5,66 $\mu \mathrm{m}$. Nilai bilangan Runkle adalah 1,10 menunjukkan kemungkinan memerlukan energi penggilingan lebih besar dan tidak mudah terfibrilisasi karena tidak mudah dipipihkan. Nilai bilangan Runkle lebih dari 1 menunjukkan bahwa serat pelepah tersebut memiliki dinding yang tebal, sebaliknya jika nilai bilangan Runkle kurang dari 1 (Pratiwi, 2000).

Tabel 1. Hasil Analisis Komponen Kimia Bahan Baku

\begin{tabular}{|c|c|c|c|}
\hline No & Parameter Analisa & Satuan & $\begin{array}{l}\text { Hasil } \\
\text { Analisa }\end{array}$ \\
\hline 1. & Kadar air & $\%$ & 9,35 \\
\hline 2. & Kadar abu & $\%$ & 2,05 \\
\hline 3. & Kadar pentosan & $\%$ & 29,40 \\
\hline 4. & Kadar lignin & $\%$ & 22,67 \\
\hline 5. & Kadar holoselulosa & $\%$ & 69,33 \\
\hline 6. & Kadar alfa selulosa & $\%$ & 40,79 \\
\hline 7. & Kadar sari & $\%$ & 3,30 \\
\hline 8. & $\begin{array}{l}\text { Kelarutan dalam air } \\
\text { panas }\end{array}$ & $\%$ & 4,92 \\
\hline 9. & $\begin{array}{l}\text { Kelarutan dalam air } \\
\text { dingin }\end{array}$ & $\%$ & 5,87 \\
\hline 10. & $\begin{array}{l}\text { Kelarutan dalam } \\
\mathrm{NaOH} 1 \%\end{array}$ & $\%$ & 25,56 \\
\hline
\end{tabular}

Dari Tabel 1 di atas dapat dilihat kadar holoselulosa adalah 69,33\%. Holoselulosa adalah bagian serat yang bebas sari (ekstraktif) dan lignin terdiri dari selulosa dan hemiselulosa, berwarna kuning putih sampai kekuning-kuningan. Kadar holoselulosa merupakan kadar total karbohidrat atau kadar polisakarida dalam bahan baku, kadar selulosa alfa adalah 40,79\%. Menurut SNI 01-1303-1989, selulosa adalah polisakarida linier, terdiri dari satuan anhidroglukosa dengan ikatan 1,4 $\beta$-glukosidik yang pada hidrolisa dalam suasana asam menghasilkan D-glukosa. Selulosa dibagi ke dalam tiga bagian yaitu $\alpha$-selulosa yang mempunyai berat molekul tinggi yang merupakan bagian yang tinggal setelah bagian selulosa lainnya larut pada perlakuan dengan natrium hidroksida 9,45\%. Pelarutan setelah terjadi pengembangan dengan natrium hidroksida 17,5\%. Sedangkan bagian selulosa yang larut dalam natrium hidroksida 9,45\% adalah $\beta$-selulosa dan $\gamma$-selulosa. Kadar sari yaitu kadar ekstraktif yang terkandung dalam bahan 
baku umumnya terdiri atas asam-asam lemak, resin, wax, gum dan lain-lain, merupakan bahan yang mudah menguap dan bahan yang tidak mudah menguap (Bouiri, 2007). Menurut SNI 14-1032-1989, sari (ekstrak alkohol-benzena) adalah zat dalam kayu atau pulp yang terekstraksi oleh alkohol-benzena sebagai pelarut dilakukan pada titik didih pelarut dalam waktu tertentu. Kadar sari untuk serat TKS adalah 3,30\%. Pada umumnya bahan baku yang mengandung kadar sari yang rendah akan menghasilkan pulp yang bersih. Presentasi kelarutan TKS dalam $\mathrm{NaOH}$ $1 \%$ adalah $25,56 \%$. Kelarutan bahan baku dalam $\mathrm{NaOH} 1 \%$, air panas dan air dingin merupakan indikator banyak komponen kimia terlarut. Tingginya kelarutan bahan baku dalam $\mathrm{NaOH} 1 \%$ dapat menunjukkan bahwa bahan tersebut mudah mengalami pelapukan atau terjadinya degradasi komponen kimia karena mikroorganisme.

Kadar lignin TKS 22,67\%, hampir sama dengan kadar lignin dalam kayu daun. Kadar lignin yang rendah menunjukkan bahwa bahan baku mudah dibuat pulp karena memerlukan energi panas dan mekanis lebih sedikit.

Pembuatan pulp dengan proses CTMP menunjukkan rendemen tertinggi diperoleh dengan penambahan dosis $\mathrm{NaOH} 4 \%$ sebesar $76,67 \%$ sedangkan rendemen terendah yaitu $63,44 \%$ dengan dosis $\mathrm{NaOH} 10 \%$. Hal ini membuktikan bahwa semakin besar dosis $\mathrm{NaOH}$ yang digunakan semakin kecil rendemen yang dihasilkan. Sedangkan pembuatan pulp dengan proses APMP menunjukkan rendemen tertinggi terhadap serat hasil depithing sebesar $69,45 \%$ dengan target low brightness diikuti pulp APMP middle brightness sebesar 69,40\%. Hasil pengujian sifat fisik lembaran pulp pada Tabel 2 di bawah ini dijadikan dasar pemilihan untuk pembuatan kertas lainer, dimana yang digunakan adalah kekuatan fisik yang paling tinggi. Berdasarkan hasil analisa sifat fisik lembaran pulp diperoleh bahwa kekuatan fisik lembaran pulp CTMP yang dibuat dengan $\mathrm{NaOH} 8 \%$ dan $10 \%$ lebih tinggi dari lembaran pulp CTMP lainnya, dan lembaran pulp APMP middle dan high brightness lebih tinggi dari low brightness. Dari hasil tersebut diputuskan bahwa CTMP 8\% dan $10 \% \mathrm{NaOH}$ serta APMP middle brightness dan high brightness dibuat kertas karton gelombang. Hasil pengujian kertas medium dari pulp mekanis TKS dengan proses CTMP $8 \%$ dan $10 \%$ serta APMP middle dan high brightness bahwa kertas medium yang terbuat dari $10 \%$ CTMP paling bagus kualitasnya dan memenuhi syarat sebagai kertas medium tipe B. Parameter kualitasnya meliputi gramatur $\left(113,1 \mathrm{~g} / \mathrm{m}^{2}\right)$, tebal $(0,2171 \mathrm{~mm})$, bulk $\left(1,82 \mathrm{~cm}^{3} / \mathrm{g}\right)$, ring crush (7,8 kgf/in), CMT (14,7 kgf), ketahanan tarik $(3,91 \mathrm{kN} / \mathrm{m})$, breaking length $(3537,3 \mathrm{~m})$, kadar air $(9,4 \%)$ dan $\mathrm{Cobb}_{60}\left(29,6 \mathrm{~g} / \mathrm{m}^{2}\right)$. Hasil pengujian kertas lainer campuran pulp TKS APMP dan OCC tidak memenuhi syarat sebagai kertas lainer merujuk dari data yang diperoleh. Menurut teori dan pengalaman di pabrik, kertas lainer biasanya dibuat dari pulp kraft serat panjang yang berasal dari impor. Sedangkan hasil pengujian kertas lainer campuran pulp TKS CTMP dan OCC dengan komposisi $75 \%$ pulp CTMP (8\%) dan 25\% OCC paling baik dan memenuhi syarat sebagai kertas lainer B dengan data yang diperoleh berdasarkan parameter analisis gramatur $\left(131,6 \mathrm{~g} / \mathrm{m}^{2}\right)$, ring crush $(14,2 \mathrm{kgf} / \mathrm{in})$, ketahanan retak $(288 \mathrm{kPa})$, kadar air $(8,2 \%), \mathrm{Cobb}_{60}\left(\mathrm{~g} / \mathrm{m}^{2}\right)$ dan indeks retak $(345 \mathrm{kN} / \mathrm{g})$.

Tabel 2. Hasil Pengujian Sifat Fisik dan Optik Lembaran Pulp CTMP dan APMP

\begin{tabular}{ccccc}
\hline No & Pulp & $\begin{array}{c}\text { Indeks Sobek } \\
(\mathrm{kN} / \mathrm{g})\end{array}$ & $\begin{array}{c}\text { Indeks Retak } \\
\left(\mathrm{kPa} . \mathrm{m}^{2} \mathrm{~g}\right)\end{array}$ & $\begin{array}{c}\text { IndeksTarik } \\
(\mathrm{Nm} / \mathrm{g})\end{array}$ \\
\hline 1. & CTMP 4\% & 5.4 & 1.34 & 27.63 \\
2. & CTMP 6\% & 5.4 & 1.75 & 28.12 \\
3. & CTMP 8\% & 5.4 & 3.10 & 40.93 \\
4. & CTMP 10\% & 4.2 & 3.58 & 49.91 \\
5. & APMP low brightness & 5.3 & 0.88 & 15.23 \\
6. & APMP middle brightness & 5.7 & 1.27 & 22.84 \\
7. & APMP high brightness & 5.6 & 1.71 & 27.77 \\
\hline
\end{tabular}


Sebagai bahan KKG, kertas lainer harus memenuhi persyaratan tertentu, terutama sifat ketahanan lingkar dan ketahanan retaknya. Di samping itu, agar KKG cukup tahan terhadap kondisi lembab, maka daya serap airnya harus dipertimbangkan pula. Hal ini diperlukan agar proses perekatan berjalan dnegan baik, sehingga diperoleh KG dan KKG dengan ketahanan tekan yang tinggi. Untuk menunjang karakteristik yang diperlukan oleh KKG, maka Standar Nasional Indonesia (SNI. 14-0095-1987) mempersyaratkan nilai gramatur, ketahanan retak, ketahanan lingkar, daya serap air, dan kadar air bagi kertas lainer. Berdasarkan nilai ketahanan retak dan ketahanan tekan lingkarnya, kertas liner diklasifikasikan menjadi kelas A dan kelas B.

Faktor yang berpengaruh terhadap ketahanan retak kertas lainer adalah panjang serat dan ikatan antar serat. Oleh karena itu, kertas lainer selalu mengandung serat panjang yang berfungsi untuk memberikan sifat kekuatan pada kertas lainer. Dengan demikian komposisi serat panjang dan serat pendek sangat menentukan sifat ketahan retak. Ikatan antar serat dipengaruhi oleh tingkat penggilingan dan penambahan bahan kimia penguat. Ada banyak bahan kimia penguat yang dapat digunakan diantaranya adalah pati kationik. Jenis ini selain dapat memperkuat lembaran, juga mampu meretensi bahan lain yang ditambahkan ke dalam stok. Jadi, semakin tinggi kandungan serat panjang dan semakin banyak bahan kimia penguat yang digunakan, maka semakin tinggi kekakuan lembaran, akibatnya ketahanan tekanan lingkarnya juga semakin tinggi.

Pada penggunaan akhir, kertas ini akan mengalami proses cetak dan tekanan akibat tumpukan atau tekanan dari bahan yang dikemasnya. Karena itu persyaratan utama dari kertas lainer adalah memiliki sifat ketahanan retak dan ketahanan lingkar (ring crush) yang tinggi. Untuk mendapatkan kedua sifat tadi maka biasanya kekuatan kertas lainer bertumpu pada penggunaan NUKP (pulp kraft serat panjang belum putih) dengan proporsi sekitar $10-20 \%$. Meskipun NUKP sudah mampu diproduksi di dalam negeri, namun dari segi harga, kertas bekas jauh lebih murah. Oleh karena itu penggunaan NUKP sebagai serat panjang banyak digantikan oleh kertas bekas disebut Old Corrugated Container (OCC). Demikian pula halnya dengan komponen serat pendek dalam kertas lainer, biasanya digunakan LUKP (pulp kraft serat pendek belum putih). Namun, karena harga LUKP cukup mahal sementara kertas bekas tersedia melimpah dan murah, maka peranan LUKP digantikan dengan kertas bekas. Dengan demikian, bahan baku untuk kertas lainer, baik serat pendek maupun serat panjang, seluruhnya adalah kertas bekas.

Dari hasil penelitian diperoleh kadar air kertas lainer maupun kertas medium sesuai SNI. Pada proses pembuatannya, kertas lainer harus mengalami proses pendarihan untuk mempertimbangkan daya serapnya terhadap air. Pada prinsipnya, bahan darih berfungsi untuk mengendalikanpenetrasicairankedalamlembaran. Kondisi yang lembab bisa menyebabkan kadar air lembaran menjadi tinggi. Pengendalian kadar air lembaran kertas lainer diperlukan terutama karena proses perekatan dan pencetakan dipengaruhi oleh faktor ini. Di samping itu, kekuatan kertas juga bisa menurun dengan naiknya kadar air lembaran. Kadar air lembaran sangat tergantung pada kondisi lingkungan dimana lembaran tersebut berada dan selalu dalam kondisi yang setimbang dengan lingkungannya. Kondisi lembab (RH tinggi) bisa menyebabkan kadar air lembaran menjadi tinggi. Proses pendarihan tidak banyak membantu mengendalikan kadar air berupa air, akan tetapi berupa uap air. Penetrasi uap air ke dalam lembaran sangat tergantung pada struktur lembaran, yang pada gilirannya juga tergantung pada bahan-bahan yang menyusun lembaran tersebut.

\section{KESIMPULAN}

1. Serat tandan kosong sawit (TKS) mempunyai morfologi serat yang cukup baik yaitu panjang serat rata-rata $1,11 \mathrm{~mm}$ dan termasuk ke dalam kelompok serat pendek. Kadar holoselulosa TKS adalah 69,33\% dan termasuk cukup baik untuk bahan baku pulp. Kadar lignin TKS 22,67\% dan hampir sama dengan kadar lignin kayu daun.

2. Hasil pembuatan pulp CTMP menunjukkan bahwa semakin besar dosis $\mathrm{NaOH}$ yang digunakan semakin kecil rendemen yang dihasilkan. Hasil pembuatan pulp APMP menunjukkan bahwa semakin besar target brightness yang didapat semakin turun rendemen yang dihasilkan. 
3. Hasil pengujian sifat fisik lembaran pulp menunjukkan bahwa pulp CTMP yang dibuat dengan $\mathrm{NaOH} 8$ dan $10 \%$ lebih tinggi dari lembaran pulp lainnya, dan lembaran pulp APMP middle dan high brightness lebih tinggi dari pulp APMP high brightness. Dengan demikian CTMP 8\% dan 10\% serta APMP middle dan high brightness akan dibuat kertas karton gelombang.

4. Dari hasil pembuatan kertas medium terlihat bahwa yang terbuat dari 100\% CTMP paling bagus kualitasnya dan memenuhi syarat sebagai kertas medium tipe B. Sedangkan hasil pembuatan kertas liner dari pulp CTMP menunjukkan kertas liner dari campuran $75 \%$ pulp CTMP dan 25\% OCC paling baik dan memenuhi syarat SNI sebagai kertas liner B.

\section{DAFTAR PUSTAKA}

Bouiri, B., Amrani, M., 2007, Production of Dissolving Grade Pulp from Alfa, Bioresources, Vol. 5 No. 1, p. $291-302$

Considine, J.M., dkk, 2010, Z-Direction Fiber Orientation In Paperboard, Tappi Journal Vol. 9 No. 10, p. 25-32
Erwinsyah, Darnoko, 2000, Particleboard From Empty Bunch Fibre. Indonesian Wood Research Society (WoRS) proceedings, August $22^{\text {nd }}-23^{\text {rd }}, 1998$, Winaya Mukti University, Indonesia.

IPPA, 2011, Indonesian Pulp and Paper Industry: Directory, Indonesian Pulp and Paper Association, Jakarta

Pratiwi, W., Sugesty, S., 2000, Dissolving Pulp Making of Acacia Mangium Wood and its Optimation, Berita Selulosa, Vol. 36 No. 1 2, 4-10, Balai Besar Selulosa, Bandung

Rolf, B., dkk, 2009, Non-Wood Pulping Technology - Present Status and Future, IPPTA Journal, Vol. 21, No. 1, p. 115-120

Tandon, R., dkk, 2009, Quality Improvement of Mixed Office Paper With Single and Multi Component Enzymes, Progress in Paper Recycling, Vol. 18, No. 2, p. 4-10

Tjahjono, J., 2005, Potensi dan Tandan Kosong Sawit sebagai Bahan Baku Pulp Kertas, Jurnal Riset Industri Perdagangan, Vol. 3 No. 1, Departemen Perindustrian dan Perdagangan 